\title{
Histological and histochemical features of the oogenesis in the simultaneous protandric hermaphrodite shrimp Exhippolysmata oplophoroides (Decapoda: Caridea)
}

\author{
Adriane A. Braga ${ }^{\mathrm{a}, *}$, Erika T. Nunes ${ }^{\mathrm{a}}$, Laura S. López-Grecco ${ }^{\mathrm{b}, \mathrm{c}}$, \\ Maria Izabel Camargo-Mathias ${ }^{\mathrm{d}}$, Vivian Fransozo ${ }^{\mathrm{e}, \mathrm{f}}$ \\ a Departamento de Biologia, Centro de Ciências Exatas, Naturais e da Saúde, Universidade Federal do Espírito Santo, 29500-000 Alegre, ES, Brazil \\ ${ }^{\mathrm{b}}$ Departamento de Biodiversidad y Biología Experimental, Facultad de Ciencias Exactas y Naturales, Universidad de Buenos Aires, Ciudad Universitaria, \\ C1428EHA Buenos Aires, Argentina \\ ' IBBEA, CONICET-UBA, Argentina \\ d Departamento de Biologia, Instituto de Biociências, Universidade Estadual Paulista, Av. 24A, 1515, Bela Vista, 13506-900 Rio Claro, SP, Brazil \\ e Departamento de Ciências Naturais, Universidade Estadual do Sudoeste da Bahia, Campus de Vitória da Conquista, Estrada do Bem Querer, Km 04, \\ 45031-900, Vitória da Conquista, BA, Brazil \\ f NEBECC (Núcleo de Estudos em Biologia, Ecologia e Cultivo de Crustáceos), Brazil
}

\section{A R T I C L E I N F O}

\section{Article history:}

Received 28 April 2016

Received in revised form 17 June 2016

Accepted 18 June 2016

Available online 25 June 2016

\section{Keywords:}

Hermaphroditism

Ovarian development

Ovotestes

Vitellogenesis

Spine-shrimp

\begin{abstract}
A B S T R A C T
This study analyzes the dynamics of the vitellogenesis process in the simultaneous protandric hermaphrodite shrimp Exhippolysmata oplophoroides, based on light microscopic observations. The ovotestes of the shrimps at the different gonadal development stages were removed, fixed and submitted an usual histological procedure (HE) and histochemical techniques (Bromophenol Blue, PAS/Alcian Blue, and Von Kossa tests). The germinative cells were classified into oogonias, and oocytes in stages I-IV based on the following features: cell size, cytoplasm appearance, presence of yolk granules, lipid droplets, chorion, and chromatin patterns. In the male initial phase of the gonadal development, the ovotestes present mainly oogonia and oocytes I and II while in the functional hermaphrodite phase, oocytes III and IV predominate in the peripheral zone of the gonads. Oocytes with an atypical appearance of the cellular components indicative of reabsorption were also observed. This study showed an increasing accumulation of proteins, carbohydrates and lipids occurring as the germ cells develop, being the yolk elements deposited in a sequence, in which proteins and carbohydrates are the first to appear both by an endogenous as well as also by an exogenous origin. The presence of calcium was detected mainly in oocytes I, II and inside those in reabsorption, being posteriorly mobilized to chorion constitution and/or to hemolymph due to its role during molting. Although the similarity of the germ cells shape among the crustaceans, this first histochemical characterization of E. oplophoproides ovary increases the comprehension of oogenesis in a caridean simultaneous protandric hermaphrodite species.
\end{abstract}

(c) 2016 Elsevier Ltd. All rights reserved.

\section{Introduction}

The Caridea shrimps are decapod crustaceans characterized by the presence of an expansion in the second abdominal segment that overlaps the first and the third ones. The reproductive biology of the caridean is marked by the diversity of sexual systems, including gonochoristic species, sequential hermaphrodites, and simultane-

\footnotetext{
* Corresponding author.

E-mail address: dricrab@yahoo.com.br (A.A. Braga).
}

ous protandric hermaphrodite (SPH) species (Baeza, 2006; Bauer, 2000, 2006).

In the SPH animals the mature individuals reproduce initially as males, and later, as functional simultaneous hermaphrodites (Baeza, 2009; Bauer and Holt, 1998; Braga et al., 2009). Based on macroscopic and microscopic observation, Braga et al. (2009) described the sexual system of Exhippolysmata oplophoroides (Holthuis, 1948), commonly known as spine-shrimp, as SPH, with the male phase being represented by the stages I and II, when the testicular portion of the gonad corresponds to up to half of its total length, later proceeding to the hermaphrodite phase (stages III-V). 
In decapod crustaceans, in general, the female reproductive system consists of a pair of ovaries connected with oviducts (Krol et al., 1992). However, Braga et al. (2009) described the existence of an posterior testicular portion besides of an anterior ovarian portion in E. oplophoroides gonad, thus classifying it as an ovotestis. According to Nunes et al. (2010), the gonad of this species presents a $H$ shape and it is located dorsally to the hepatopancreas, in a ventral position in relation to the heart, extending to the dorsal-caudal region of the cephalothorax.

The development of the gonads in carideans is accompanied by modifications in the ovaries with gonadal cells multiplication and gametes growth for maturation, ovulation and oviposition (Grassé, 1996). The oogenesis in decapods is a process that involves germ cells and accessory somatic cells which consists in three successive phases: previtellogenesis, vitellogenesis and maturation as commonly noted in light microscopy studies (Ferreira et al., 2012; Kang et al., 2008; Medina et al., 1996; Meeratana and Sobhon, 2007; Mossolin and Bueno, 2002; Okumura and Aida, 2000; Okumura et al., 2005; Zara et al., 2013). Overall, little is known about the gonadal activity of carideans. Morphological studies referring to the ovarian stages of Macrobrachium acanthurus (Wiegmann, 1836) (Carvalho, 1980; Carvalho and Pereira, 1981), Pandalus hypsinotus Brandt, 1851 (Okumura et al., 2004), Macrobrachium amazonicum (Heller, 1862) (Chaves and Magalhães, 1993), Macrobrachium rosenbergii De Man, 1879 (Meeratana and Sobhon, 2007) and E. oplophoroides by Braga et al. (2009) can be highlighted. In the latter species also the development of the testicular portion of the ovotestis has been characterized (Nunes et al., 2010).

The present study aimed to analyze the female germ cells at different stages of maturation and their distribution according to the gonadal development of E. oplophoroides, as well as to verify, through histochemical analysis, the presence of proteins, carbohydrates, lipids and calcium $\left(\mathrm{Ca}^{2+}\right)$ in these cells. The information obtained in this study will certainly allow following with greater precision the ovarian modifications which occur throughout vitellogenesis, providing a better understanding on the reproductive physiology of this caridean species.

\section{Materials and methods}

\subsection{Sampling method}

Exhippolysmaya oplophoroides shrimps were collected in Ubatuba Bay, on northern coast of the state of São Paulo, Brazil, using a fishing boat equipped with two double ring trawl nets. A total of 487 individuals were measured at their caparace length (CL) and ranged from 3.5 to $14.6 \mathrm{~mm}$. Then, fifteen specimens of each stage of gonadal development (I, II, III, IV and V), as previously defined by Braga et al. (2009) based on color and size of the gonads, were separated. Under a stereoscope microscope, the ovotestes were removed from the dorso-anterior region of the cephalothorax for the light microscopic analysis.

\subsection{Light microscopy procedures}

Gonads were fixed in Karnovsky's solution (glutaraldehyde 2\%, paraformaldehyde $4 \%$ in phosphate buffer $0.1 \mathrm{M}, \mathrm{pH} 7.3$ ), during $24 \mathrm{~h}$. The dehydration was carried out using an ascending sequence (70-95\%) of ethyl alcohol, and then, the material was included in methacrylate resin (Leica Historesin, Nussloch/Heidelberg, BadenWürttemberg, Germany). The polymerized blocks were sectioned using a dry glass knife in Leica RM microtome. The sections of $3 \mu \mathrm{m}$ thickness were stained with Hematoxylin and Eosin according to Junqueira and Junqueira (1983), for the histological routine. The histochemical testswere applied as described below, aiming to detect the presence of proteins (Bromophenol Blue), neutral and acid polysaccharides (Periodic Acid-Schiff- PAS/Alcian Blue), and calcium (Von Kossa).

- Bromophenol blue: the slides with sections were maintained in the Bromophenol blue stain during $2 \mathrm{~h}$ at room temperature, and after washing in $0.5 \%$ acetic acid for five minutes, they were washed in water for $15 \mathrm{~min}$ and they were passed quickly through butyl acid solution.

- PAS- Alcian blue: after kept in Alcian blue pH 2.5 during 30 min, the slides were washed in distilled water, followed by a $1 \%$ periodic acid bath for $5 \mathrm{~min}$. They were maintained in Schiff's reagent for $30 \mathrm{~min}$ in the dark after washing in water. Afterwards, the sections were washed in sulfurous water $(10 \mathrm{ml}$ of solution $10 \%$ sodium metabisulfite, $1 \mathrm{ml}$ of hydrochloric acid, $89 \mathrm{ml}$ of distilled water) for $1 \mathrm{~min}$ and in water for $10 \mathrm{~min}$.

- Von Kossa: the sections were submitted to $5 \%$ silver nitrate solution for 20 min in the dark and posteriorly, washed in water. After placed in Kodak D72 developer (Eastman Kodak, Rochester, NY, USA) for $2 \mathrm{~min}$ and in $5 \%$ sodium thiosulfate solution for $5 \mathrm{~min}$. The sections were counterstained with hematoxylin for six minutes.

The presence of lipid droplets was identified as structures without coloration.

The slides were mounted in Canada Balsam. The analysis and digital images were made using a Motic BA 300 photomicroscope from the Histology Laboratory of the Biology Department at the Biosciences Institute, UNESP, Rio Claro, State of São Paulo, Brazil. Cell measurements were taken using the software LEICA LAS EZ 3.0.0: Leica Microsystems with appropriate calibration for the objective lens used. The longest diameter of oocytes from slides stained with hematoxylin and eosin (HE) was measured using a $10 \times$ and $40 \times$ objectives. Slides of at least three individuals were used to examine the germ cells. Thirty cells of each stage of development were measured. Averages as well as standard deviations were calculated and analyzed by ANOVA test followed by a Tukey's multiple comparison test $(\mathrm{a}=0.05)$ using the Past Software (Quinn and Keough, 2002).

\section{Results}

The ovarian portion of E. oplophoroides ovotestis is constituted by two lobes, joined in the middle region (Fig. 1A, D). This area is lined by a muscle layer and connective tissue, with squamous cells that penetrate the organ dividing it into lobes. Inside these lobules, germ cells can be seen organized as strings at the initial development stages (Fig. 1A, B). Latero-ventrally to each ovarian lobe begins an oviduct, constituted by simple cubic epithelium lined with muscle cells. Follicular cells of cubic or oval shape, with chromatin predominantly positioned close to the nuclear membrane and presenting evident nucleolus, are seen involving clusters of oogonia and each oocyte separately (Figs. 1,2), constituting the socalled ovarian follicles. In the follicles containing more developed oocytes, these follicular cells become squamous (Figs. 1F, 2). The gonads in stage $\mathrm{V}$ were marked by the presence of various empty follicles (Fig. 4B).

The ovarian parenchyma presents germ cells in different number and stages of differentiation (Figs. 1-4, ). The classification of such cells was made based on: size, location, cytoplasmic appearance, visualization of the nucleus and chromatin pattern, accumulation of yolk granules, and the presence of chorion and lipid droplets in the cytoplasm. Each lobule is filled with oocytes showing a pronounced increase in diameter, with significant differences (ANOVA F $=1050, \mathrm{P}=0.0000)$ (Table 1$)$. 

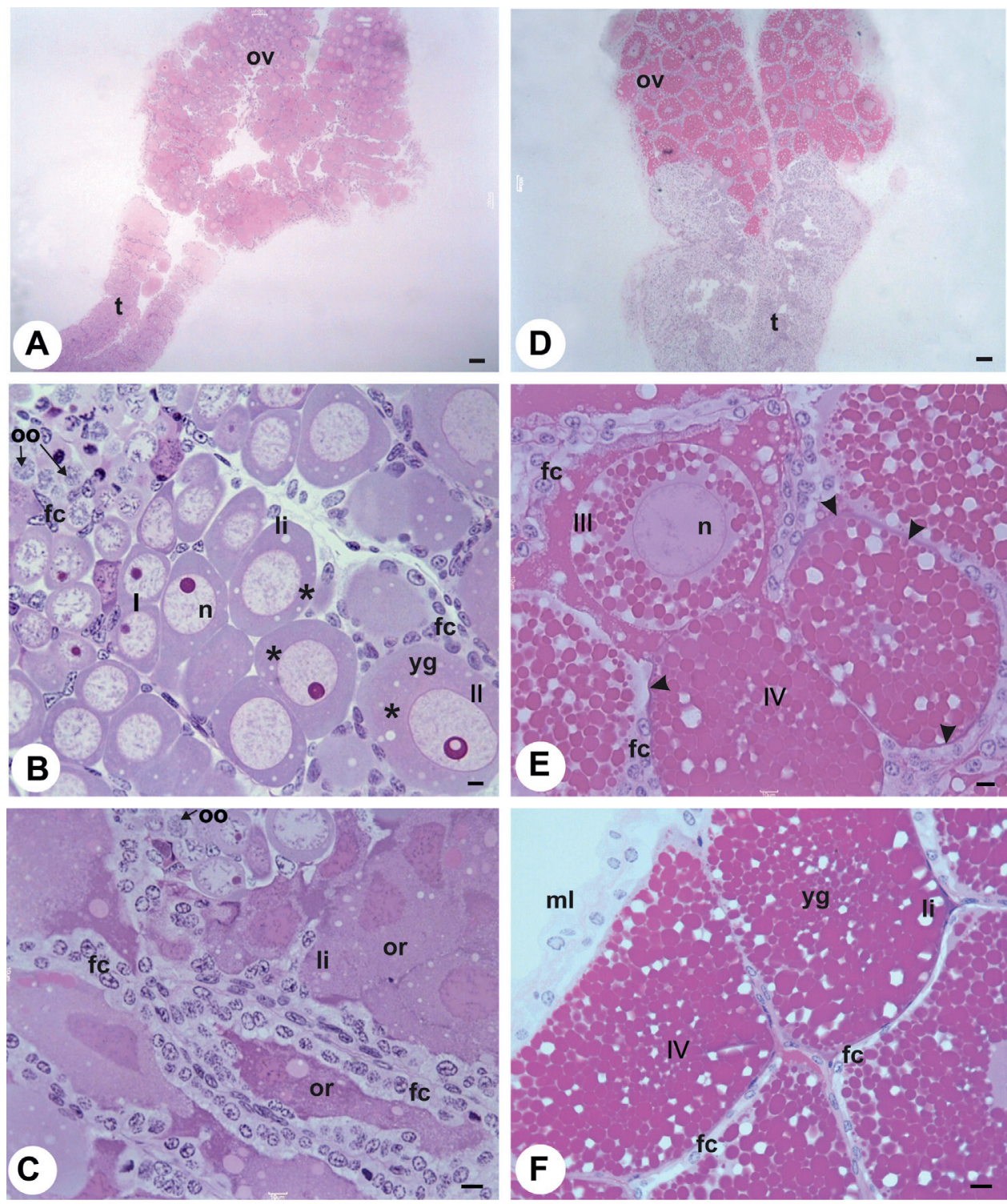

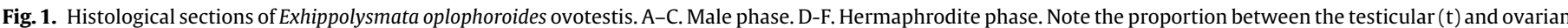

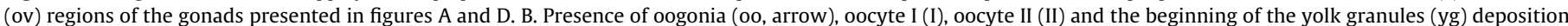

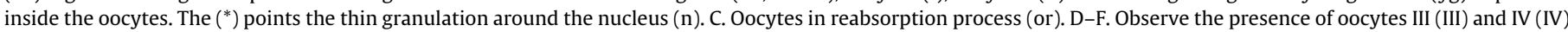

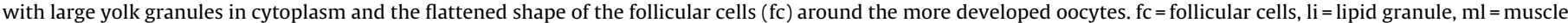
layer, head arrow = chorion. Bars: $A, D=100 \mu \mathrm{m} ; \mathrm{B}, \mathrm{C}, \mathrm{E}, \mathrm{F}=10 \mu \mathrm{m}$. Stain: Hematoxylin-eosin $(\mathrm{H}-\mathrm{E})$.
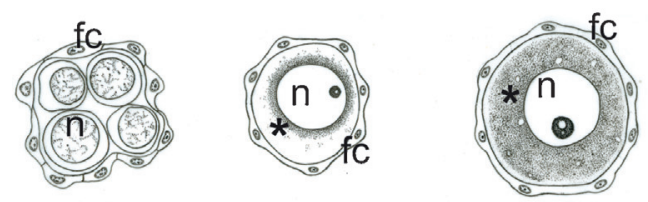

oogonia

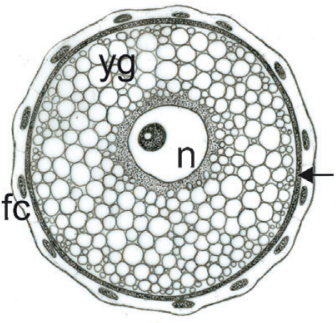

oocyte III

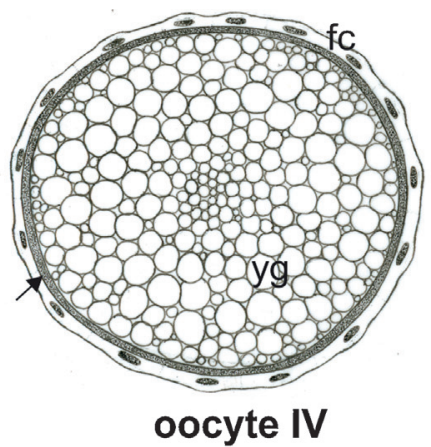

oocyte IV

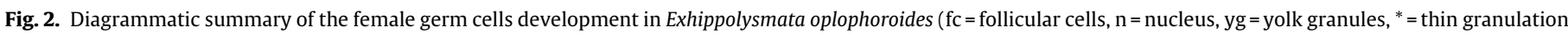
in cytoplasm, arrow = chorion). 

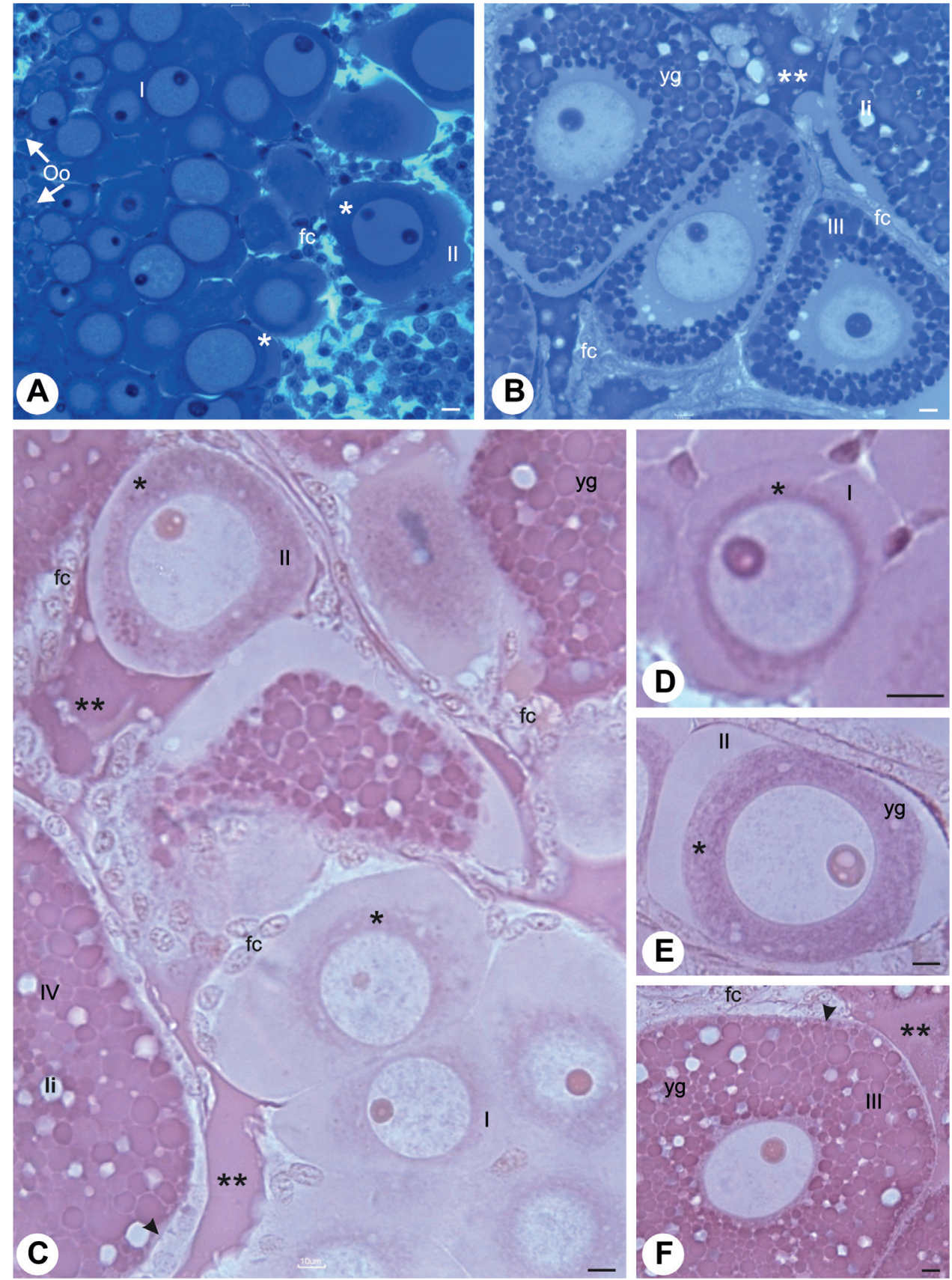

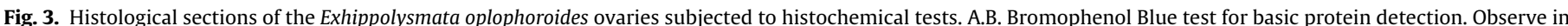

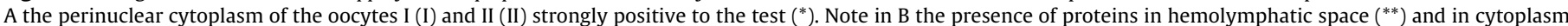

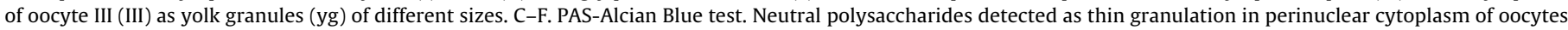

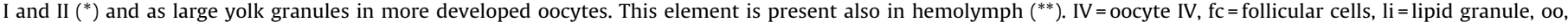
arrow $=$ oogonia, head arrow $=$ chorion. Bars $=10 \mu \mathrm{m}$.

Table 1

Morphological characteristics of the female germ cells of Exhippolysmata oplophoroides shrimps.

\begin{tabular}{|c|c|c|c|c|c|c|c|}
\hline \multirow[t]{2}{*}{ Germ cell } & \multirow[t]{2}{*}{ Mean $(\mathrm{mm}) \pm \mathrm{SD}$} & \multirow[t]{2}{*}{ Chorion } & \multirow[t]{2}{*}{ Nucleolus } & \multicolumn{4}{|c|}{ Cytoplasmic granules } \\
\hline & & & & Protein & Polysacharide & Lipid & Calcium \\
\hline Oogonia & $0.016 \pm 0.003^{\mathrm{a}}$ & NV & NV & + & - & - & + \\
\hline Oocyte I & $0.075 \pm 0.09^{b}$ & NV & $\mathrm{V}$ & ++ & + & $-1+$ & +++ \\
\hline Oocyte II & $0.084 \pm 0.01^{\mathrm{b}}$ & NV & V & ++ & ++ & + & +++ \\
\hline Oocyte III & $0.169 \pm 0.02^{c}$ & $\mathrm{~V}$ & V & +++ & +++ & ++ & ++ \\
\hline Oocyte IV & $0.302 \pm 0.05^{\mathrm{d}}$ & V & NV & +++ & +++ & ++ & ++ \\
\hline
\end{tabular}

"Different letters indicated a significant difference. (NV) not visible; (V) visible; (-) negative; (+) weakly positive; (++) moderately positive; (+++) strongly positive 

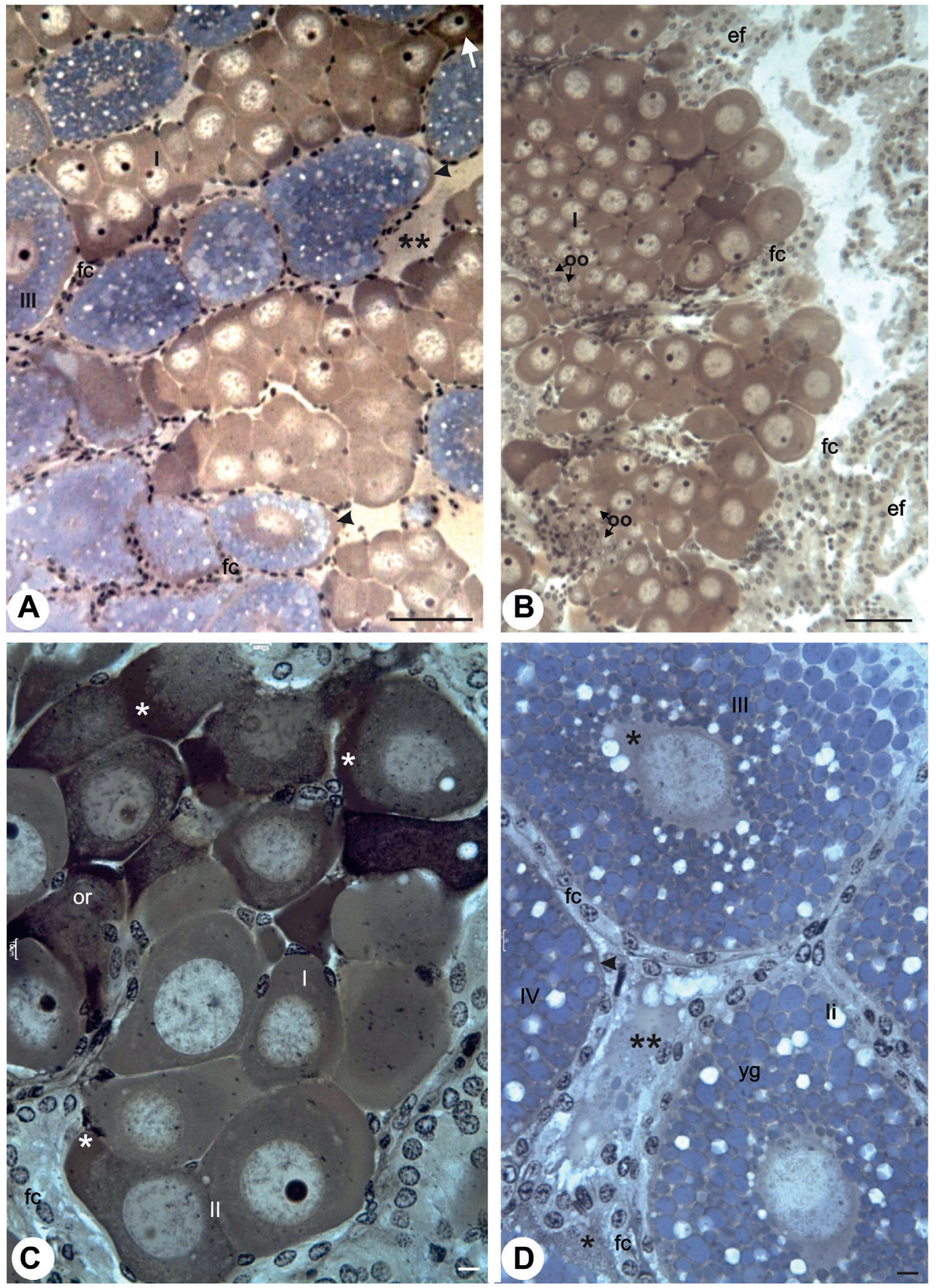

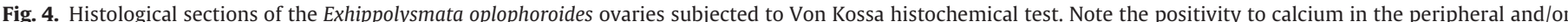

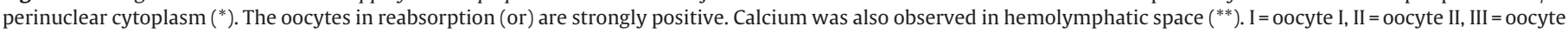
III, IV = oocyte IV, ef = empty follicle, $\mathrm{fc}=$ follicular cells, li = lipid granule, oo, arrow = oogonia, head arrow $=$ chorion. $\mathrm{Bars:} \mathrm{A}, \mathrm{B}=100 \mu \mathrm{m}, \mathrm{B}-\mathrm{C}=10 \mu \mathrm{m}$.

\subsection{Description of the cell}

- Oogonia: small cubic cells with diameter of $0.016 \pm 0.003 \mathrm{~mm}$, located in the central portion of the ovary (oogenic region). They possess a large nucleus, with non-evident nucleolus and narrow and homogeneous cytoplasmic mass, without evidence of granulation (Figs. 1B, 2, 3A).

- Oocytes I: larger cells than oogonia, with diameter of $0.075 \pm 0.09 \mathrm{~mm}$, located in the previtellogenic region of the ovary. Their shape varies from round to elliptical, and the scarce cytoplasm contains thin granulation. The nucleus is large and presents non-condensed chromatin; one or two nucleoli can be observed in its interior (Figs. 1B, 2, 3A, C-D).
- Oocytes II: larger than oocytes I, with diameter of $0.084 \pm 0.01 \mathrm{~mm}$, characterized by large quantity of small granules, predominantly located close to the nucleus. This nucleus is central and exhibits evident nucleolus, sometimes in ring shape (Figs. 1B, 2, 3A, C, E).

- Oocytes III: cells with diameter of $0.169 \pm 0.02 \mathrm{~mm}$ located in the vitellogenic region of the gonad. They are marked by the intense vitellogenic granulation, with granules of different sizes and degrees of basophilia distributed all over the cytoplasm. The smaller granules are preferentially found close to the nucleus and in the periphery of the cell. The nucleus possesses one or two nucleoli, and is still evident. A thick chorion can be seen (Figs. 1E, 2, 3B, F). 
- Oocytes IV: considered to be in advanced degree of development, they are the largest cells, with diameter of $0.302 \pm 0.05 \mathrm{~mm}$, moving towards the side of the organ as they mature (mature zone). The cells contain large, dense yolk granules, occupying the entire cytoplasm, which hinders the visualization of the nucleus. The chorion is also seen (Figs. 1F, 2, 3C, 4D). Some amorphous oocytes, in reabsorption process, presenting intensely vacuolated cytoplasm and mostly non-distinguishable nuclei are also found in all stages of gonadal development (Figs. 1C, 4C), but in varying quantities.

During the male phase (stages I and II) of the ovotestis gonad of $E$. oplophoroides, it is possible to observe the predominance of oogonia and oocytes I as well as some oocytes II and in reabsorption process (Fig. 1A-C). However, the end of the male phase (stage II) is marked by the presence of only oocytes I and II.

In the hermaphrodite phase (stages III-V) of the ovotestis gonad of $E$. oplophoroides all cells of the germ line can be observed, more precisely, in stage III of the gonad there is predominance of oocytes III (Fig. 1E) along with some oocytes I and II. When the gonad is in stage IV, it is possible to observe oocytes IV occupying great part of the ovarian parenchyma, with some oogonia and oocytes I located at the center of the organ. The stage $\mathrm{V}$ has a predominance of oogonia and oocytes I, similarly to gonad I, differing from it by many empty follicles being found in the peripheral region, as a consequence of the release of oocytes IV into the oviduct (Fig. 4B).

\subsection{Histochemistry}

\subsubsection{Detection of proteins}

Weakly positive reaction was observed in the oogonia. Oocytes I, II and in reabsorption process were marked by a moderate amount of substances with protein properties distributed in the peripheral cytoplasm; in the region proximal to the nucleus of oocytes I and II, the cytoplasm appeared strongly positive (Fig. 3A). Similar intensely positive reaction was verified in the nuclear envelope and in the nucleoli of all oocytes. The dense yolk granules present in the cytoplasm of the oocytes III and IV had intense marking, especially the smaller and more peripheral ones (Fig. 3B). The presence of proteins was also detected close to oocytes III and IV, in the hemolymphatic space (Fig. 3B). Follicular cells presented weakly stained cytoplasm, while the chorion showed moderate positivity.

\subsubsection{Detection of polysaccharides}

Oocytes I presented weak and uniform cytoplasmic positivity for neutral polysaccharides, in the shape of thin granulation close to the nucleus (Fig. 3C, D); in turn, oocytes II presented moderate reaction to the test (Fig. 3C, E). The oocytes III and IV had positive marking in the yolk granules, especially the more peripheral ones (Fig. 3C, F), as well as in the nuclear envelope and the nucleoli. Positive staining was also observed in the hemolymphatic space (Fig. 3C, F). Neither the oogonia nor the follicular cells reacted to the employed test. However, the chorion presented positivity for Periodic Acid-Schiff stain (PAS).

\subsubsection{Detection of calcium}

The oogonia presented weak reaction to the calcium detection test, while oocytes III and IV presented moderate quantity of this element among yolk granules (Fig. 4A, D). Oocytes I, II and in reabsorption process appeared strongly positive, with heterogeneous distribution of calcium, sometimes concentrated in the periphery of the cell and other times in the perinuclear region (Fig. 4C). The follicular cells reacted weakly to the calcium test, but the chorion was intensely marked (Fig. 4D). There was also marking for this element in the hemolymphatic space (Fig. 4C, D). In oocytes III, IV and those undergoing reabsorption, moderate quantity of large lipid droplets was found (Figs. 1C, 3E, F, C, F, 4A, D). Scarce lipid granules were observed in the oocytes I, whereas in oocytes II the cytoplasm presented some lipid droplets of various sizes (Figs. 1B, $3 \mathrm{C}, \mathrm{E}$ ). This component was not observed in the oogonia neither in the follicular cells.

\section{Discussion}

In the last years, research on the sexual system of $E$. oplophoroides has been carried out to understand its reproductive biology (Baeza et al., 2010; Braga et al., 2009; Nunes et al., 2010), who reported the presence of an ovotestis and classified this species as protandric simultaneous hermaphrodite. Using histological techniques on the ovary of $E$. oplophoroides modifications in the oocytes of this shrimp and their arrangement close to the follicular cells were described.

During maturation, the follicular cells become squamous, responding to the increase of oocytary volume, which results in a lower epithelium. In this sense, Yano and Chinzei (1987) demonstrated in the penaeid shrimp Penaeus japonicus Spence Bate, 1888, that vitellogenin can be synthesized in the follicular cells, secreted into the hemolymph and then collected by the oocytes. Differently, according to Adiyodi and Subramonian (1983), in crustaceans the follicular cells participate in the collection of yolk proteins into the oocytes. However, in E. oplophoroides, this alteration in the shape of follicular cells during oocyte maturation does not seem to be related to vitellogenin production, but rather to the transfer of hemolymph components to the oocytes, as well as to chorium formation, and/or to the stretching caused by growth of the oocytes. Using the applied histochemical tests, this could be confirmed by the fact that no intense marking was seen in the cytoplasm of these cells.

Meeratana and Sobhon (2007) classified the follicular cells found in $M$. rosenbergii in type I and type II follicular cells, where the first are ellipsoid and during oocyte maturation become flattened, having strongly stained chromatin, while the type II exhibits little change in shape, has a lighter-colored more ovoid nucleus and forms a layer around the type I cells. However, in the present study, the distinct observed morphologies are related to the activity of these cells during vitellogenesis of the oocyte which they line. In accordance with Chaves and Magalhães (1993), cell hypertrophy occurs after elimination of the oocyte, a characteristic also verified in this study, where the follicular cells reassume the cubic morphology found at the initial vitellogenesis stages.

Oocytes were found undergoing reabsorption in all stages, but their quantities varied. Zara et al. (2013) also reported presence of oocytes in reabsorption, as they were not discharged during ovulation, or else empty atretic follicles, in the ovigerous females of Callinectes danae Smith, 1869, and the authors highlighted the participation of follicular cells and hemocytes in this process. These cells have hydrolytic enzymes which may be participate in the digestion process of yolk granules (Adiyodi and Subramonian, 1983).

In this study, the oogonia and oocytes I and II presented cytoplasm strongly reactive to hematoxylin. As maturation progresses, the cytoplasm becomes acidophilic due to the accumulation of yolk granules, a feature that agrees with the results obtained for Artemesia longinaris Bate, 1888 and Panulirus echinatus Smith, 1869 by Dumont and D'Incao (2004) and Barreto et al. (2008), respectively. The cells increase drastically in size and weight, as they initiate yolk production. According to Chaves and Magalhães (1993), the color alteration is due the granules properties and this is also related to the decrease of cytoplasmic organelles of the pre-vitellogenic phase (oocyte I).

The development of oocytes and their distribution in the gonads of $E$. oplophoroides were characterized by two main features: (1) 
their progressive maturation from the center to the periphery, with the presence of oogonia and oocytes I-III registered in the central region of the ovary, referred to as germ or proliferative zone by Browdy (1989); (2) and by a movement of more developed cells to the periphery, close to the oviduct, corroborating Braga et al. (2009). This localization is due to the rapid multiplication of the central germ cells, which causes the displacement of the primary oocytes to the periphery of the ovarian lobes, classified by Meeratana and Sobhon (2007) as vitellogenic zone.

Regarding the size of E. oplophoroides germ cells, significant differences are observed in the diameter, similar to those reported for M. rosenbergii (Meeratana and Sobhon, 2007). Althoug, oocytes IV of the present study were much smaller than those corresponding to mature oocytes of $P$. hypsinotus (875-975 $\mu \mathrm{m}$ ) (Okumura et al., 2004), which demonstrates that there are variations in the size of germ cells, even among carideans.

According to Braga et al. (2009), macroscopically the gonads of E. oplophoroides in stages II (rudimental) and V (exhausted) presented the same size, differing only in the flaccid aspect of gonad $\mathrm{V}$. However, the present histological analysis demonstrated that both differ with regard to the predominant germ cells, in that some oocytes I to IV can be seen in the gonads in stage II while those in stage $\mathrm{V}$, after oviposition, exhibit various oogonia, oocytes I and II, and empty follicles. Okumura et al. (2004) indicate that, after the release of eggs period, the remaining non-vitellogenic oocytes reinitiate the development of the new ovarian cycle, as occurs in other crustacean Pleocyemata species (Minagawa and Sano, 1997; Okumura and Aida, 2000; Okumura, 2003).

According to Browdy et al. (1990) and Krol et al. (1992), during vitellogenesis the ovary accumulates organic and inorganic elements from the yolk for oocyte maturation, as water, proteins and lipids. In E. oplophoroides gonad, the materials of protein origin are already observed in the cytoplasm of germ cells at the beginning of the development (oogonia); lipids and polysaccharides are detected upon maturation of oocytes I. Although Zara et al. (2013) assumed that polysaccharides are the first reserves accumulated during pre-vitellogenesis in $C$. danae. Blue staining of bromophenol inside of all cells in differentiation (from oogonia to oocyte $V$ ) correspond to the proteins of the oocytes cytoplasm, which will be important to embryos development as well as to young individual survival.

This difference in protein distribution in the oocytes of $E$. oplophoroides (more intense and homogeneous in the cytoplasm close to the nucleus of oocytes I and II, as well as in the peripheral cytoplasm of oocytes III and IV) indicates that protein synthesis initially occurs in the oocyte itself and later also exogenously, with marking being verified also in the hemolymphatic space. In more advanced oocytes (IV and mature) of the $M$. rosenbergii, Meeratana and Sobhon (2007) also observed an increase in size and acidophily due to accumulation of yolk protein, suggesting derivation from an extra ovarian source. Similarly, Zara et al. (2013) observed positive marking for protein, not in granular form, in the cytoplasm of $C$. danae oocytes at juvenile and rudimental phases. These authors also verified a dilated rough endoplasmic reticulum in the mentioned phases probably due its protein synthesis that are.

Similarly, in P. hypsinotus (Okumura et al., 2004), it was verified that the endogenous vitellogenic oocytes present well-developed rough endoplasmic reticulum containing small electron dense protein granules, not consisting of vitellin. However, the exogenous vitellogenic oocytes have yolk grains with vitellin whose origin is the hemolymph vitellogenin (Okumura et al., 2004). According to Okumura et al. (2006), the vitellogenin synthesis occurs in hepatopancreas and ovaries, being after its transference to the oocytes cytoplasm, stored as vitellin. Other authors propose that both the hepatopancreas and the adipose tissue are sources of yolk proteins (Jasmani et al., 2004; Tsutsui et al., 2000; Yang et al., 2000).
The present findings indicate that the deposition of polysaccharides increased with the gradual development of the germ cells. The localization of this component indicates that, at initial stages, polysaccharides originate from endogenous synthesis and are later obtained from the intercellular space. An intensely positive reaction to PAS was also verified, as occurred with regard to protein deposition, as observed by Okumura et al. (2004) P. hypsinotus oocytes. According to Tsukimura (2001), in many crustacean species, the vitellogenin from hemolymph is collected and modified into vitellin inside the oocytes by the addition of polysaccharides and lipids, what explain the stain profile of protein and polysaccharide detection at oocytes III and IV.

Moreover, the exogenous origin of the polysaccharides at more advanced stages of vitellogenesis is also important to compose the chorion, a membrane that emerges in the oocyte III stage as a layer that reacts moderately to the PAS test. Similar membrane was observed in the intermediate oocytes of $C$. danae, also composed of neutral polysaccharide and protein (Zara et al., 2013). In E. oplophoroides, despite starting to appear already in the cytoplasm of stage-I oocytes, colorless lipid granules were found in large quantity in the oocytes III and IV. Studying vitellogenesis in $M$. amazonicum, Chaves and Magalhães (1993) also observed the presence of large quantity of non-stained vesicles in mature oocytes or oocytes in advanced vitellogenesis. According these authors, the vesicles consisted of phospholipids, which are essential for the synthesis of cell membranes after fertilization. In C. danae, Zara et al. (2013) verified the presence of many small droplets of lipid among yolk granules occupying the entire cytoplasm of the mature oocytes; and the nucleus was rarely visualized, as also verified in oocytes IV of this study.

The presence of the calcium in the hemolymphatic space of the E. oplophoroides ovary and its prior accumulation in oocytes I and II, turning this organ into a temporary calcium storage site. With progressing development of the oocytes, the calcium is possibly mobilized for constitution of the chorion that appears in oocytes III, with an intense marking for the element being hence verified in this membrane. Moreover, the great accumulation of calcium verified in the cells in reabsorption indicates that this element is stored in E. oplophoroides oocytes, and reused and redirected to the hemolymph in case it is not used. According to Luquet and Marin (2004), during post-molt the $\mathrm{Ca}^{2+}$ will help compose the hardening exoskeleton, constituting a continuous flow of the ion. The histological techniques performed in the present study allowed understanding the phenomena that occur at cell level during the differentiation of the gonads, making it possible to follow with greater precision the cell modifications during the vitellogenic development of E. oplophoroides. Moreover, the histochemical analysis detected the deposition of nutritious materials, both by autosynthesis and from exogenous synthesis, in the cytoplasm of the germ cells that will warrant the development of the future embryo.

\section{Acknowledgements}

We thank Gerson Mello Souza for the technical support; the Biology Department of UNESP, Rio Claro (SP), Brazil for availability of Histology and Electron Microscopy laboratories; the NEBECC group (Group of studies on Crustacean Biology, Ecology and Culture) for the support during shrimps samplings; the Instituto Brasileiro do Meio Ambiente e Recursos Naturais Renováveis (IBAMA) for permission to collect shrimps; and Tatiana Gasparazzo for the English revision. 


\section{References}

Adiyodi, R.G., Subramonian, T., 1983. Arthropoda-Crustacea. In: Adiyodi, K.G., Adiyodi, R.G. (Eds.), Reproductive Biology of Invertebrates, Oogenesis, Oviposition and Oosorption, vol. 1. Wiley - Sons, New York, pp. 443-495.

Baeza, J.A., Braga, A.A., López-Greco, L.S., Perez, E., Negreiros-Fransozo, M.L., Fransozo, A., 2010. Population dynamics, sex ratio and size at sex change in a protandric-simultaneous hermaphrodite, the spiny shrimp Exhippolysmata oplophoroides. Mar. Biol. 157, 2643-2653.

Baeza, J.A., 2006. Testing three models on the adaptive significance of protandric simultaneous hermaphroditism in a marine shrimp. Evolution 60, 1840-1850.

Baeza, J.A., 2009. Protandric simultaneous hermaphroditism is a conserved trait in Lysmata (Caridea: Lysmatidae): implications for the evolution of hermaphroditism in the genus. Smithson. Contrib. Mar. Sci. 38, 95-110.

Barreto, A.V., Silva, J.R.F., Atsuragawa, M.E., Raposo, M.C.F., 2008. Desenvolvimento dos ovários da lagosta Panulirus echinatus (Crustacea: Palinuridae) baseados nas análises macroscópica, microscópica e relação gonadossomática (RGS). Rev. Bras. Zool. 25 (4), 689-695

Bauer, R.T., Holt, G.J., 1998. Simultaneous hermaphroditism in the marine shrimp Lysmata wurdemanni (Caridea: Hippolytidae): an undescribed sexual system in the decapod Crustacea. Mar. Biol. 132, 223-235.

Bauer, R.T., 2000. Simultaneous hermaphroditism in caridean shrimps: a unique and puzzling sexual system in the Decapoda. J. Crust. Biol. 20, 116-128.

Bauer, R.T., 2006. Same sexual system but variable sociobiology: evolution of protandric simultaneous hermaphroditism in Lysmata shrimps. Integr. Comp. Biol. 46, 430-438.

Braga, A.A., López-Greco, L.S., Santos, D.C., Fransozo, A., 2009. Morphological evidence for protandric simultaneous hermaphroditism in the caridean Exhippolysmata oplophoroides. J. Crust. Biol. 29 (1), 34-41.

Browdy, C.L., Fainzilber, M., Tom, M., Loya, Y., Lubzens, E., 1990. Vitellin synthesis in relation to oogenesis in in vitro incubated ovaries of Penaeus semisulcatus (Crustecea, Decapoda, Penaeidae). J. Exp. Zool. 255, 205-215.

Browdy, C.L., 1989. Aspects of the reproductive biology of Penaeus semisulcatus De Haan (Crustacea; Decapoda, Penaeidae). Ph.D. Thesis. Tel. Aviv. University, Israel (138 pp)

Carvalho, H.A., Pereira, M.C.G., 1981. Descrição dos estádios ovarianos de Macrobrachium acanthurus (Wiegmann 1836) (Crustacea, Palaemonidae) durante o ciclo reprodutivo. Ciênc. Cult. 33 (10), 1353-1358.

Carvalho, H.A., 1980. Morfologia do aparelho reprodutor de Macrobrachium acanthurus (Wiegmann, 1836) (Crustacea, Decapoda, Palaemonidae) Parte IMasculino. Ciênc. Cult. 32 (7), 941-945.

Chaves, P.T., Magalhães, C.O., 1993. Desenvolvimento ovocitário em Macrobrachium amazonicum (Heller, 1862) (Crustacea: Decapoda: Palaemonidae), camarão dulcícola da região amazônica. Acta Amaz. 23 (1), 17-23.

Dumont, L.F.C., D’Incao, F., 2004. Estágios de desenvolvimento gonadal de fêmeas do camarão-barba-ruça (Artemesia longinaris - Decapoda: Penaeidae) Iheringia. Ser Zool. 94 (4), 389-393.

Ferreira, M.A.P., Resende, B.M., Lima, M.Y.S., Santos, S.S.D., Rocha, R.M., 2012. The stages of ovarian development affects organ expression of vitellogenin as well as the morphometry and ultrastructure of germ cells in the freshwater prawn Macrobrachium amazonicum (Heller, 1862). Theriogenology 78, 981-990.

Grassé, P.P., 1996. Traité de Zoologie: Anotomie, Systématique, Biologie. Tome VII. Crustacés; fascicule I: Morphologie, Physiologie, Reproduction, Systématique. Masson Paris.

Jasmani, S., Ohira, T., Jayasankar, V., Tsutsui, N., Ainda, K., Wilder, M.N., 2004. Localization of vitellogenin mRNA expression and vitellogenin uptake during ovarian maturation in the giant freshwater prawn Macrobrachium rosenbergii. J. Exp. Zool. A Comp. Exp. Biol. 301, 334-343.

Junqueira, L.C.U., Junqueira, L.M.M.S., 1983. Técnicas básicas de citologia e histologia. São Paulo, Santos.
Kang, B.J., Nanri, T., Lee, J.M., Saito, H., Han, C.H., Hatakeyama, M., Saigusa, M., 2008 Vitellogenesis in both sexes of gonochoristic mud shrimp, Upogebia major (Crustacea): analyses of vitellogenin gene expression and vitellogenin processing. Comp. Biochem. Physiol. Part B 149, 589-598.

Krol, R.M., Hawkins, W.E., Overstreet, R.M., 1992. Reproductive components. In: Harrison, F.W., Humes, A.G. (Eds.), Microscopic Anatomy of Invertebrates Vol 10: Decapod Crustacea. Wiley-Liss, New York, pp. 259-343.

Luquet, G., Marin, F., 2004. Biomineralizations in Crustacean: Storage strategies. C.R. Palevol. 3 (6-7), 515-534.

Medina, A., Vila, Y., Mourente, G., Rodríguez, A., 1996. A comparative study of the ovarian development in wild and pond-reared shrimp, Penaeus kerathurus (Forslkal, 1775). Aquaculture 148, 63-75.

Meeratana, P., Sobhon, P., 2007. Classification of differentiating oocytes during ovarian cycle in the giant freshwater prawn, Macrobrachium rosenbergii De man. Aquaculture 270, 249-258.

Minagawa, M., Sano, M., 1997. Oogenesis and ovarian development cycle of the spiny lobster Panulirus japonicus (Decapoda:Palinuridae). Mar. Freshwater Res. $48,875-887$.

Mossolin, E.C., Bueno, S.L.S., 2002. Reproductive biology of Macrobrachium olfersi (Decapoda, Palaemonidae) in São Sebastião. Brazil. J. Crust Biol. 22 (2), 367-376.

Nunes, E.T., Braga, A.A., Santos, D.C., Camargo-Mathias, M.I., 2010. Cytodifferentiation during the spermatogenesis of the hermaphrodite caridea Exhippolysmata oplophoroides. Micron 41, 585-591.

Okumura, T., Aida, K., 2000. Hemolymph vitellogenin levels and ovarian development during the reproductive and non-reproductive molt cycles in the giant freshwater prawn Macrobrachium rosenbergii. Fish. Sci. 66, 678-685.

Okumura, T., Yoshida, K., Nikaido, H., 2004. Ovarian development and hemolymph vitellogenin levels in laboratory-maintained protandric shrimp, Pandalus hypsinotus: measurement by a newly developed time-resolved fluoroimmunoassay (TR-FIA). Zool. Sci. 21, 1037-1047.

Okumura, T., Nikaido, H., Yoshida, K., Kotaniguchi, M., Tsuno, Y., Seto, Y., Watanabe, T., 2005. Changes in gonadal development, androgenic gland cell structure, and hemolymph vitellogenin levels during male phase and sex change in laboratory-maintained protandric shrimp, Pandalus hypsinotus (Crustacea: Caridea: Pandalidae). Mar. Biol. 148, 347-361.

Okumura, T., Kim, Y.K., Kawazoe, I., Yamano, K., Tsutsui, N., Aida, K., 2006 Expression of vitellogenin and cortical rod proteins during induced ovarian development by eyestalk ablation in the Kuruma prawn, Marsupenaeus japonicus. Comp. Biochem. Physiol. Part A 143, 246-253.

Okumura, T., 2003. Relationship of ovarian and marsupial development to the female molt cycle in Acanthomysis robusta (Crustacea: Mysida). Fish. Sci. 69, $995-1000$.

Quinn, G.P., Keough, M.J., 2002. Experimental design and data analysis for biologists. Cambridge Universit Press, New York.

Tsukimura, B., 2001. Crustacean vitellogenesis: its role in oocyte development. Am. Zool. 41, 465-476.

Tsutsui, N., Kawazoe, I., Ohira, T., Jasmani, S., Yang, W.J., Wilder, M.N., Aida, K., 2000. Molecular characterization of a cDNA encoding vitellogenin and its expression in the hepatopancreas and ovary during vitellogenesis in the kuruma prawn, Penaeus japonicus. Zool. Sci. 17, 651-660.

Yang, W.J., Ohira, T., Tsutsui, N., Subramoniam, T., Huong, D.T.T., Aida, K., Wilder, M.N., 2000. Determination of amino acid sequence and site of mRNA expression of four vitellins in the giant freshwater prawn, Macrobrachium rosenbergii. J. Exp. Zool. 287, 413-422.

Yano, I., Chinzei, Y., 1987. Ovary is the site of vitellogenin synthesis in Kuruma prawn, Penaeus japonicus. Comp. Biochem. Physiol. 86B, 213-218.

Zara, F.J., Gaeta, H.H., Costa, T.M., Toyama, M.H., Caetano, F.H., 2013. The ovarian cycle histochemistry and its relationship with hepatopancreas weight in the blue crab Callinectes danae (Crustacea: Portunidae). Acta Zool. 94, 134-146. 